\title{
NOTE ON THE TECHNIQUE OF MAKING BACTERIA-FREE CULTURES OF MARINE DIATOMS
}

\author{
By S. P. Chu \\ Ray Lankester Investigator at the Plymouth Laboratory
}

There is a great demand for algal cultures in studying morphology, cytology, ecology, cellular pathology and physiology, identification of species, and biotic interaction, and also in feeding small animals in culture for various studies. It is hoped that the following note may be of some use to those who want to start making pure cultures of marine phytoplankton organisms.

Bacteria-free cultures can be obtained directly by washing diatom cells (Chu, 1942; Pringsheim, 1921, 1936, 1937) with frequent change of the medium used for washing. It is, however, advisable to obtain first a flourishing crude unialgal culture, the 'persistent culture' of Allen \& Nelson (I9IO), as a preparatory measure for making bacteria-free cultures. The bacteria-free culture of Nitzschia closterium forma minutissima used in my experiments (Chu, 1946) was isolated from a subculture from Allen's persistent culture. Diatom cells were first inoculated into the artificial sea water made with pure inorganic chemicals as described below, and cultured in low temperature and high-light intensity. The absence of dissolved organic substance in the medium, the high-light intensity and the low temperature are factors which are very effective in reducing bacterial growth. The cultures were artificially illuminated at night and exposed to bright daylight whenever possible, but not to direct sunlight. They were kept at IO- $\mathrm{I}^{\circ} \mathrm{C}$. by means of running water, and were aerated by compressed air which was filtered through sterilized cotton-wool. Subcultures were made when the rate of multiplication was at its maximum (usually during the third day after inoculation). The inoculum was about half a million cells in each 500 c.c. culture. After several successive subcultures the number of bacteria was greatly reduced. Distinct bacterial growth was still obtained when inoculation from one of the sixth subcultures was made either in nutrient sea-water broth or on nutrient sea-water agar. When a drop from this sixth subculture was examined under oil immersion, however, no bacterium could be detected on the surface of some of the Nitzschia cells. Selected single healthy Nitzschia cells from this subculture were washed through drops of Berkefeld filtered or artificial sea water, five separate drops being contained in each sterilized Petri dish and a new sterilized micropipette used for each drop. Twenty-five drops were found to be quite sufficient to get rid of the bacteria, each drop containing approximately o.I c.c. The micropipettes and the Petri dishes (with well-fitted lids) were sterilized 
beforehand, and the sterilized sea water was added before it was used for washing.

The washed diatom cells were then inoculated (five cells on to each agar plate or into each Io c.c. of liquid media) into the following media:

(I) Artificial sea water (Io c.c. in each of the $150 \times 16 \mathrm{~mm}$. pyrex testtubes. If no bacteria-free cultures could be obtained from the washed diatom cells, more successive subcultures would be made from this culture in order to reduce the bacterial number still further).

(2) Nutrient sea-water broth (consisting of dextrose, sodium acetate, Difco beef extract and peptone, each $0.1 \%$, in artificial sea water, or Berkefeldfiltered sea water enriched with $\mathrm{NaNO}_{3}, \mathrm{Na}_{2} \mathrm{HPO}_{4}, \mathrm{Na}_{2} \mathrm{SiO}_{3} .9 \mathrm{H}_{2} \mathrm{O}$, and Fe-citrate, 50, 5, I0, and 0.5 parts per million respectively), Io c.c. in each I $50 \times$ I $6 \mathrm{~mm}$. Pyrex test-tube.

(3) Sea-water agar ( $1.5 \%$ agar in artificial sea water with the amounts of nitrate, phosphate, silicate and citrate doubled, or in Berkefeld-filtered natural sea water enriched with $\mathrm{NaNO}_{3}, \mathrm{Na}_{2} \mathrm{HPO}_{4}, \mathrm{Na}_{2} \mathrm{SiO}_{3} .9 \mathrm{H}_{2} \mathrm{O}$, and Fe-citrate, I00, I0, 20, and I parts per million respectively).

(4) Nutrient sea-water agar [I.5\% agar in artificial sea water with the amounts of nitrate, phosphate, silicate and citrate doubled (or Berkefeld-filtered natural sea water enriched with $\mathrm{NaNO}_{3}$ I00, $\mathrm{Na}_{2} \mathrm{HPO}_{4}$ IO, $\mathrm{Na}_{2} \mathrm{SiO}_{3} .9 \mathrm{H}_{2} \mathrm{O} 20$, and $\mathrm{Fe}$-citrate I parts per million) further enriched with dextrose, sodium acetate, Difco beef extract and peptone, each $0 \cdot 1 \%]$.

Bacterial growth occurred only in one of the five nutrient agar-plate cultures (medium 4), while the other four plate cultures proved to be bacteriafree. There was no bacterial growth in any of the cultures in nutrient broth (medium 2) or on sea-water agar plates (medium 3). When I c.c. from a culture in medium I (artificial sea water) was inoculated on a nutrient agar plate, no bacterial growth developed. Subcultures were made on nutrient agar slant from each of the cultures which were without evident bacterial growth, and these were then incubated in the dark at room temperature $\left(20-22^{\circ} \mathrm{C}\right.$.). All of these except one proved to be bacteria-free. Hereafter one of the subcultures inoculated from one of the bacteria-free nutrient agar plates has been subcultured successively in nutrient agar slants.

This nutrient sea-water agar (medium 4) has been proved to be very suitable for keeping bacteria-free cultures of marine diatoms. It is good for bacterial growth, and any contamination will soon become visible from the colonies developed. At the same time it is also good for the growth of marine diatoms. When there is no need for the diatom to grow rapidly, slant cultures, before reaching the maximum growth, may be removed from good illumination to some distance from a north window where the light is not strong (I00-200 f.c. for a large part of the day), and subcultures may be made once every 3-6 months. They can also be stored in a large glass jar covered with a cotton pad.

The quality of the nutrient agar differs with the method of preparation. The method used was as follows. I5 g. of the agar fibre (B.D.H.) is put into a 
flask, 500 c.c. of tap water added, and the level of the water marked on the flask. The agar is then washed with running tap water for I day and with distilled water for another day. After returning the washed agar into the marked flask, the artificial or enriched Berkefeld-filtered natural sea water is added to the mark. This is autoclaved (at $20 \mathrm{lb}$. pressure for $5 \mathrm{~min}$.) separately with the nutrient solution which consists of

$\begin{array}{lclc} & \text { Parts per million } & & \text { Parts per million } \\ \text { Dextrose } & 2000 & \mathrm{Na}_{2} \mathrm{HPO}_{4} & 7.5 \\ \text { Sodium acetate } & 2000 & \mathrm{Na}_{2} \mathrm{SiO}_{3} \cdot 9 \mathrm{H}_{2} \mathrm{O} & \mathrm{I} 5 \\ \text { Peptone } & 2000 & \mathrm{FeC}_{6} \mathrm{H}_{5} \mathrm{O}_{7} \cdot 3 \mathrm{H}_{2} \mathrm{O} & 0.8 \mathrm{I} \\ \mathrm{NaNO}_{3} & 75 & & \end{array}$

in 500 c.c. of artificial or enriched sea water. When the autoclave is opened after the pressure has dropped to zero, the aqueous agar, while still hot, is decanted and mixed with the nutrient solution. The mixture is poured into sterilized test-tubes or Petri dishes before they cool below $45^{\circ} \mathrm{C}$. If contamination is suspected the agar tubes and plates are sterilized in a steamer for $20 \mathrm{~min}$. If the nutrient agar is not prepared satisfactorily and the diatom fails to grow, the agar plates and slants can be improved by being impregnated each with 4 c.c. of clear sterilized soil extract which is poured over the agar surface and is absorbed by the agar.

A small droplet (containing about 50 cells) from the fifth preparatory subculture in artificial sea water was inoculated, without further washing, on the agar surface (medium 3). Besides a large colony of $N$. closterium, which was mixed with bacteria, several small colonies also developed later, some distance apart from the large mass of growth. These small colonies were formed from single cells which had moved away from the mother colony. The bacterial growth in the large colony was not obvious, but when it was subcultured into media 2 and 4, bacterial growth was obtained. Subcultures from two of the small colonies were, however, proved to be bacteria-free. This shows that when the diatom cells moved through the agar, the bacteria on them were pushed off. Thus for motile diatoms this provides another method for obtaining bacteria-free cultures.

Before inoculating on to the nutrient agar, bacterial growth can be further reduced by first inoculating on to the silica gel, which can support good growth of diatoms but not bacteria. It was prepared according to Pringsheim's method (1926, p. 30I) by mixing equal volumes of diluted $\mathrm{HCl}$ (sp.gr. I.I) and diluted water-glass (sp.gr. I.08). These were diluted to the required specific gravity with the help of a hydrometer. The acid-silicate mixture was poured into Petri dishes up to a depth of about $3 \mathrm{~mm}$. The silicic acid formed set as a gel, and when the gel was well hardened the plates were washed, first in running tap water for 2 days or more until free from acid, and then several times in distilled water. The plates were then drained, covered with 5 c.c. of the artificial sea water for $24 \mathrm{hr}$., put in an oven at $60^{\circ} \mathrm{C}$. until the surface was fairly dry, and sterilized in a steamer for an hour. 
Five washed diatom cells were inoculated separately on the same silica gel plate, and subcultures made successively from the very edge of the largest colony developed until a culture was obtained which is proved to be bacteriafree when inoculated on to the nutrient agar. Sometimes small colonies were formed apart from the mother colony by single cells moved away from it. More than half of the subcultures inoculated from such small colonies proved to be bacteria-free.

The lids of Petri dishes used for making silica gel and agar plates must fit well in order to avoid contamination from the air. After inoculation the lids are fastened tightly against the dishes with an adhesive paper strip. For the inoculation during the process of making bacteria-free cultures, a micropipette as used for washing is found to be more suitable than a platinum wire, as the former can pick up cells from the margin of the colony with less disturbance to the rest of the colony where bacteria may be abundant. The platinum wire is, however, more convenient for making inoculations from bacteria-free cultures.

The artificial sea water was first used when the author was working in the Marine Station at Millport during I942. It proved to be satisfactory for the growth of a number of marine diatoms, such as Asterionella japonica Cleve \& Möller, Biddulphia mobiliensis (Bail.) Grun, Chaetoceros didymus Ehr., Coscinodiscus excentricus Ehr., Ditylium Brightwelli (West) Grun, Fragilaria striatula Lyngb., Nitzschia seriata Cleve, Rhizosolenia alata Brightw., Streptotheca thamensis Shrubs., and Thalassiothrix longissima Cleve \& Grun. Its composition is largely based on the combination of ions in sea water as suggested by Lyman \& Fleming (I940) and Thompson \& Robinson (I932).

Artificial sea water

\begin{tabular}{|c|c|c|c|}
\hline & Parts per million & & Parts per million \\
\hline $\mathrm{NaCl}$ & 23,477 & $\mathrm{Na}_{2} \mathrm{SiO}_{3} \cdot 9 \mathrm{H}_{2} \mathrm{O}$ & Io \\
\hline $\begin{array}{l}\mathrm{MgCl}_{2} \\
\mathrm{Na}_{0} \mathrm{SO}\end{array}$ & $4,98 \mathrm{I}$ & $\mathrm{Al}_{2}\left(\mathrm{SO}_{4}\right)_{3}$ & 3 \\
\hline $\begin{array}{l}\mathrm{Na}_{2} \mathrm{SO}_{4} \\
\mathrm{CaCl}_{2}\end{array}$ & $\begin{array}{l}3,917 \\
I, 102\end{array}$ & $\mathrm{BaCl}_{2} \cdot 2 \mathrm{H}_{2} \mathrm{O}$ & $\begin{array}{l}0.09 \\
0.24\end{array}$ \\
\hline $\mathrm{KCl}{ }^{2}$ & $\begin{array}{r}1,102 \\
664\end{array}$ & $\mathrm{MnCl}_{2}$ & 0.2 \\
\hline $\mathrm{NaHCO}_{3}$ & 192 & $\mathrm{LiNO}_{3}$ & I \\
\hline $\mathrm{KBr}$ & 96 & $\mathrm{FeC}_{6} \mathrm{H}_{5} \mathrm{O}_{7} \cdot 3 \mathrm{H}_{2} \mathrm{O}$ & 0.54 \\
\hline $\mathrm{H}_{3} \mathrm{BO}_{3}$ & 26 & $\mathrm{CuSO}_{4} \cdot 5 \mathrm{H}_{2} \mathrm{O}$ & 0.4 \\
\hline $\mathrm{SrCl}_{2}{ }^{\circ}$ & 24 & $\mathrm{KI}$ & 0.06 \\
\hline $\mathrm{NaF}^{2}$ & 3 & $\mathrm{As}_{2} \mathrm{O}_{3}$ & 0.03 \\
\hline $\mathrm{NaNO}_{3}$ & 50 & $\mathrm{ZnSO}_{4} \cdot 7 \mathrm{H}_{2} \mathrm{O}$ & 0.01 \\
\hline IPO & 5 & & \\
\hline
\end{tabular}

The last eleven chemicals listed above, were often dissolved in the following minor elements solution, I c.c. of which was added to I 1 . of the artificial sea water:

Minor elements solution

$\begin{array}{lrlc} & \text { Parts per million } & & \text { Parts per million } \\ \mathrm{Na}_{2} \mathrm{SiO}_{3} \cdot 9 \mathrm{H}_{2} \mathrm{O} & 10,000 & \mathrm{FeC}_{6} \mathrm{H}_{5} \mathrm{O}_{7} \cdot 3 \mathrm{H}_{2} \mathrm{O} & 540 \\ \mathrm{Al}_{2}\left(\mathrm{SO}_{4}\right)_{3} & 3,000 & \mathrm{CuSO}_{4} \cdot 5 \mathrm{H}_{2} \mathrm{O} & 400 \\ \mathrm{MnCl}_{2} & 200 & \mathrm{KI} & 60 \\ \mathrm{BaCl}_{2} \cdot 2 \mathrm{H}_{2} \mathrm{O} & 90 & \mathrm{As}_{2} \mathrm{O}_{3} & 30 \\ \mathrm{RbHCO}_{3} & 340 & \mathrm{ZnSO}_{4} \cdot 7 \mathrm{H}_{2} \mathrm{O} & 10 \\ \mathrm{LiNO}_{3} & \mathrm{r}, 000 & & \end{array}$


Variation of the concentration of any of the major constituents over a certain range makes no important difference to the growth in this medium. The concentrations of nitrate and phosphate are those within the range supporting optimum growth of the marine diatoms studied, but well below the concentrations which have definite prohibiting effects on the growth. Good growth has been obtained by adding a little Laminaria ash, and omitting the last ten salts. A piece of Laminaria frond is first ashed, and then dissolved in weak $\mathrm{HCl}$ and neutralized with $\mathrm{NaOH}$ before use.

Another medium, which proved to be very helpful in obtaining crude but flourishing unialgal cultures, was used in the early stages of making the bacteria-free culture of Nitzschia seriata Cleve. It consists of a layer of baked sea-mud powder which is covered by a layer of natural sea water, or the above artificial sea water, in test-tubes of convenient size with a capacity of about 25 c.c. The idea was derived from the works of Jacobsen (I9IO) and Pringsheim (I92I and later works), who succeeded in obtaining subcultures in soil and water. The bottom mud collected from Plymouth Sound was dried, pulverized, wrapped in a layer of linen or filter paper (preferably Whatman No. 54I), about $\mathrm{I} \frac{1}{2}$ in. in length, fitted into the bottom of test-tubes which were then plugged with cotton-wool and sterilized in an electric oven at $120^{\circ} \mathrm{C}$. for half an hour. Then the sterilized natural or artificial sea water was poured into the tubes up to about $I_{2} \frac{1}{2}$ in. over the mud powder block. The whole preparation, pulverized dry mud covered with liquid in cotton-wool-plugged test-tubes, can also be sterilized at once by autoclaving at $15 \mathrm{lb}$. pressure for half an hour, or by steaming in a steamer for 3 or $4 \mathrm{hr}$. If unialgal culture only is ultimately required, but not a bacteria-free culture, the steaming sterilization is preferable, as it sometimes results in a better growth for certain organisms. A crushed grain of wheat or barley put into the mud sometimes improves the growth. If too much acid comes into solution from the mud, the addition of a little lime or calcium carbonate into the mud block is advisable. This mud solution can be used for culture the day after it is sterilized. It often provides a good growth for starting the process of making bacteria-free cultures.

It is important that the inoculum into this mud solution should contain no other alga than the one required. Single diatom cells can easily be isolated from a fresh sample collected from the sea, free from other organisms except bacteria, by the washing method described above. Washing through only ten drops of water is often enough for this purpose. It is advisable to make several such crude cultures, some inoculated with only a single washed cell, while a few others with five or more washed cells, in case some of the washed cells may fail to multiply or some of the mud solution preparations may contain something inhibiting growth. The selected cells for isolation must be healthy. The size of the chromatophore and the intensity of its colour can be of great help in judging the healthiness of diatom cells.

This method is found to be one of the safest to get the alga required 
from the sea into culture. From this mud solution culture, a large inoculum, about 50 or more cells per Io c.c. of medium, can be sown into the artificial sea water, and then one can proceed to make bacteria-free cultures as described above for $N$. closterium forma minutissima.

Both isolation of single cells and inoculation of subcultures can be carried out in a convenient isolating chamber (Chu, 1942) within which a suitable flame is available. The following device, however, has also been used and proved to be convenient and effective in avoiding contamination during the processes of making subcultures, as well as inoculating culture series in experiments and taking samples from them for examination. The apparatus used consists of a basin containing hot water which is heated either on a hot plate or by inserting an electric heater into the water; a Bunsen burner fixed on the edge of the basin, and provisions to hold the pipette, and cotton-wool plugs if required, over the hot water. As the cotton-wool plug is removed from the culture flask or tube, its neck is passed into the Bunsen flame. When a portion of the culture is being taken from or added to the flask or tube, it is held over the steam bath. The sterilized pipette used is suspended over the steam bath throughout the operation. When samples are removed from the flask to sample tubes, the latter are placed in a container which is put into the steam bath. Hence throughout every phase of the operation the apparatus and samples are protected from infection by the rising steam. The method is easy and simple, and yet very convenient and effective; it could be used in any laboratory.

As mentioned before, the absence of organic matter in the artificial sea water, strong illumination and low temperature are the effective factors in reducing the bacterial growth in the preparatory cultures. When artificial illumination is used, the electric light should pass through a screen of cold water before reaching the cultures (Chu, I942) in order to eliminate the heat effect and reduce the infra-red radiation. A I000 W. lamp is to be recommended (though a $500 \mathrm{~W}$. lamp will also serve the purpose), and the cultures could be hung just outside and about I in. apart from the bell jar holding the water where a light intensity of no less than 30,000 metre-candles can be obtained. The temperature should be as low as conveniently possible. A low temperature of $8^{\circ} \mathrm{C}$. was found to be more satisfactory than higher temperatures. The rate of multiplication of bacteria decreases with decreasing temperature in this region, but low temperature was found to have no unfavourable effect on the growth of diatoms.

The author is indebted to Dr J. W. G. Lund for reading over this paper and for making helpful suggestions. 


\section{REFERENCES}

Allen, E. J. \& Nelson, E. W., I910: On the artificial culture of marine plankton organisms. Fourn. Mar. Biol. Assoc., Vol. vIII, pp. 42I-74.

CHU, S. P., I942. The influence of the mineral composition of the medium on the growth of planktonic algae. Part I. Methods and culture media. Fourn. Ecol., Vol. $\mathrm{xxx}, \mathrm{pp} .284-325$.

- 1946. The utilization of organic phosphorus by phytoplankton. Fourn. Mar. Biol. Assoc., Vol. xxvi, pp. 285-95.

JACOBSEN, H. C., I9I0. Kulturversuche mit einigen niederen Volvocaceen. Zeitschr. Bot., Bd. II, pp. I45-88.

Lyman, J. \& Fleming, R. H., 1940. Composition of sea water. Fourn. Mar. Research, Vol. III, pp. 134-46.

Pringsheim, E. G., I92I. Algenkultur. Handb. biol. ArbMeth. Abt. XI, Teil II, pp. $377-406$.

I926. Kulturversuche mit chlorophyllführenden Mikroorganismen. V. Mitteilung. Methoden und Erfahrungen. Beitr. Biol. Pfl., Bd. xIv, pp. 283-3I2.

- 1936. Zur Kenntnis saprotropher Algen und Flagellaten. I. Über Anhäufungskulturen polysaprober Flagellaten. Arch. Protist. Bd. LxxxvII, pp. 43-96.

- 1937. Beiträge zur Physiologie saprophytischer Algen und Flagellaten. I. Chlorogonium und Hyalogonium. Planta, Bd. xxvI, p. 63 I.

Thompson, T. G. \& Robinson, R. J., I932. Chemistry of the sea. Physics of the earth. Vol. v. Oceanography, pp. 95-203. Nat. Res. Council Bull., No. 85. Washington, D.C. 